This article is presented in English with abstracts in Spanish and Portuguese

Brazilian Journal of Applied Technology for Agricultural Science, Guarapuava-PR, v.7, n.2, p.109-119, 2014

\title{
Bibliographic Review
}

\section{Abstract}

Rice culture can suffer great damages due to fungal diseases which affect seeds, roots, leaves and panicles, among which the blast disease stands out. In this context, the chemical control through fungicide use takes a key role, promoting healing, protecting and eradicative effects of the disease. The great majority of fungicides recommended include active ingredients of systemic action ways, that is, capable of penetrating and moving inside plants, being able to exert its effect in a different location from that applied. This study presents a review about the systemic fungicide use for blast disease control. For this disease, there are 25 registered commercial products which include 12 different active ingredients, considering seed treatment and foliar application, involving a total of 6 distinct ways of systemic action. The treatment with systemic fungicides has been shown efficient in chemical control for promoting healing, protecting and eradicating effects of the disease.

Keywords: Oryza sativa; phytopathology; fungicides

\section{El Añublo del arroz}

\section{Resumen}

El cultivo del arroz puede sufrir daños importantes debido a enfermedades causadas por hongos que afectan a las semillas, las raíces, las hojas y panículas, entre los que destaca el Añublo (bruzone). En este contexto, el control químico mediante el uso de fungicidas detiene un papel clave, en la promoción del efecto curativo, protector y de erradicación de la enfermedad. La gran mayoría de los fungicidas recomendados incluyen ingredientes activos con modo de acción sistémica, es decir, capaces de penetración y translocación en plantas, con alguna capacidad de ejercer su efecto en sitios diferentes donde se aplicó. Este artículo presenta una visión general del uso de fungicidas sistémicos para el control del Añublo del arroz. Para esta enfermedad, existen 25 productos comerciales registrados que incluyen 12 diferentes ingredientes activos, teniendo en cuenta el tratamiento de semillas y aplicación foliar, totalizando6 modos diferentes de acción sistémica. El tratamiento con fungicida sistémico se muestra como eficaz en el control químico, promoviendo muchas veces efectos curativos de malezas mediante la promoción de efectos de cura, protección y erradicación de la enfermedad.

Palabras clave: Oryza sativa; patología vegetal; fungicidas

\section{Brusone na cultura do arroz}

\section{Resumo}

A cultura do arroz pode sofrer grandes danos em decorrência de doenças fúngicas que afetam sementes, raízes, folhas e panículas, entre as quais destaca-se a brusone. Neste contexto, o controle químico através do uso de fungicidas assume um papel chave, promovendo efeito curativo, protetor e erradicante da doença. A grande maioria dos fungicidas recomendados incluem ingredientes ativos de modo de ação sistêmico, ou seja, capazes de penetrarem e se translocarem dentro das plantas, com alguma capacidade de exercer seu efeito em um local diferente daquele em que foi aplicado. Este trabalho

Aceppted for publication: 21/07/13.
Recived at: 10/08/13.
1 Agronomist, Doctoral student in the graduate school program in Phytotechny, Escola Superior de Agricultura Luiz Queiroz, ESALQ,
Piracicaba, São Paulo, Brasil. Avenida Pádua Dias, 11. CEP: E-mail: leonardowsoares@ibest.com.br
2 Agronomist, Master's student in the graduate school program in Agronomia, Agricultural Sciences College of Botucatu, Universidade
Estadual Paulista Júlio de Mesquita Filho, UNESP. E-mail: juanpiero1@gmail.com
3 Agronomist, PhD, Soil Department. Universidade Federal de Santa Maria, UFSM. E-mail: rafaelpbortolotto@gmail.com
4 Agronomist, Master's student in the graduate school program in Soil Science. Universidade Federal de Santa Maria, UFSM. E-mail:
douglasdnpg@gmail.com
5 Agronomy student at Universidade Federal de Santa Maria, UFSM. E-mail: eduardogruhn@hotmail.com

Applied Research \& Agrotecnology 07 n2 may/sep. (2014)

Print-ISSN 1983-6325 (On line) e-ISSN 1984-7548 
apresenta uma revisão sobre o uso de fungicidas sistêmicos para controle de brusone. Para esta doença, há 25 produtos comerciais registrados que incluem 12 ingredientes ativos diferentes, considerando-se tratamento de sementes e aplicação foliar, envolvendo no total 6 modos de ação sistêmicos distintos. O tratamento com fungicidas sistêmicos tem se mostrado eficiente no controle químico, por promover muitas vezes efeitos curativo, protetor e erradicante da doença.

Palavras-chave: Oryza sativa; fitopatologia; fungicidas

\section{Introduction}

Rice (Oryza sativa) is one of the world's oldest plants to be cultivated. It is a plant of tropical origins broadly cultivated in the world in a variety of areas. This areas cover more than 100 countries, in all continents, except Antarctic, from latitude $50^{\circ} \mathrm{N}$ to $40^{\circ} \mathrm{S}$, and from sea level to a $3000 \mathrm{~m}$ altitude, including predominantly tropical, temperate and subtropical regions, Brazil being the biggest rice producer in the Western Hemisphere (CRUZ e MILACH, 2000; FAO, 2012).

The importance of rice culture for Brazil is known and increases as the Brazilian population contingent raises. Traditionally, rice has been cultivated in Brazil in two environments: floodplains and highlands. In floodplains, the rice is conducted in naturally flooded areas (floodplain rice), or with controlled irrigation (irrigated rice), or without irrigation (lowland rice). In highlands, the rice is mainly cultivated in areas with no irrigation (upland rice). In Brazil, the differences between the two cultivating environments are clear, demanding, even, that different improvement programs with distinct aims and different genetic bases be established for each of them (GUIMARÃES et al., 2006).

During its cycle, rice is affected by diseases that reduce the productivity and quality of the grains. More than 80 diseases caused by pathogens, including fungi, bacteria, virus and nematodes, were registered in the literary review, in different countries (FILIPPI et al., 2004). In Brazil, the main diseases in highland and irrigated rice include rice blast, grain spots, brown spots and scald. There are also records that in the past few years there was an increased incidence of Rhizoctonia blight in Rio Grande do Sul. The Rhizoctonia oryzae has been also assuming importance in Tocantins State (PRABHU et al., 2006; FILIPPI et al., 2004).

The integrated management of the diseases requires a set of preventive measures, which encompasses the genetic resistance of the cultivated variety, the cultivation practices and chemical control with fungicides, having as objective the reduction of the pathogen population to tolerable levels, not compromising the quantity and quality of the rice.

The majority of fungicide products currently registered in the Ministry of Agriculture, Livestock and Food Supply (MAPA) for rice cultivation is systemic, or includes systemic components in case of mixture of active ingredients (AGROFIT, 2003). Systemic fungicides were initially developed in the 60 's, and have since made possible greater flexibility in the chemical control of the crop (KNIGHT et al., 1997). They are considered more efficient over leaves and flowers than contact fungicides due to its properties of crossing the cuticle and move inside the plant, being able of eradicating the pathogenic fungi after penetrating the parenchyma, interrupting the infection (ERWIN, 1973; GARCÍA et al., 2003).

Rice blast - Magnaporthe grisea (Pyricularia grisea = Pyricularia oryzae)

Among the rice diseases, the rice blast, whose causative agent is the fungus Magnaporthe grisea, correspondent to anamorphic stage Pyricularia grisea (Pyricularia oryzae), is the most expressive in Brazil, causing significant losses in cultivated varieties yield, when the environmental conditions are favorable (MELLO e URASHIMA, 2003; PRABHU e FILIPPI, 2006).

In most specialists' opinion, there is no morphologic base for separating Pyricularia oryzae from Pyricularia grisea, because both have the same perfect stage, Magnaporthe grisea. Since the two genders are synonyms and as, by the nomenclature rule, the oldest name must prevail, the correct name of the anamorph is Pyricularia grisea (BEDENDO e PRABHU, 2005).

The first records about its occurrence were made in China and Japan in 1637, when the disease was initially called rice fever. The rice blast denomination is adapted from the Italian term "bruzone". In English, it's known as rice blast. In Brazil, the first verification of the disease was made by Averna-Sacca in 1912 in São Paulo State (BEDENDO e PRABHU, 2005). 
Blast disease in rice culture

El Añublo del arroz

Brusone na cultura do arroz
Basically, the pathosystem of the rice blast is divided in two subsystems: the leaf pathosystem and the panicle pathosystem (TENG, 1994). According to BEDENDO e PRABHU (2005), the most susceptible period for leaves to rice blast occurs in the vegetative phase, between 20 and 55 days after the emergence of seedlings; and the grain filling stage, between 10 and 20 days after the emission of panicles, is the most susceptible phase to rice blast in the panicles. The authors comment that the fungus can survive in the form of mycelium or conidia, in crop residues, seeds and rice plants that remain in the field. The infected seed constitutes one of the primary sources of inoculums, but even infected, it doesn't trigger an epidemic in well conducted cultivations, where the sowing uniformity is maintained, since the conidia dissemination occurs mainly through the wind. According to Lobo (2004a), the plant resistance to the pathogen increases with the plant age, starting from 55 or 60 days after the emergence, resulting in a reduction of rice blast severity in the leaves.

However, the rice blast can occur in all the plant shoot, from the initial developing stages until the final seed production phase (BEDENDO e PRABHU, 2005). The losses caused by the rice blast can be direct or indirect, whereas in the leaves it is indirect and affects the photosynthesis and respiration (BASTIAANS e KROPFF, 1993). The effect of a lesion over the liquid photosynthesis rate can be a reduction correspondent to a loss up to three times the area occupied by that lesion (BASTIAANS e ROUMEN, 1993). In the panicles, the damages are direct, due to its effect in different components of the production. BASTIAANS (1993) points out that a severe epidemic of the disease can occur during the maximum tillering, provoking senescence of leaves. The tillering period can then be prolonged, delaying the flourishing and maturity. The plant growth and the foliar area formation decreases drastically during the establishment of the disease, continuing reduced until the maturity, resulting in severe loss of dry matter and grain productivity, although the dry matter distribution may not be affected. Production components, such as the panicle number, 1000 grains weight and proportion of formed grains are affected negatively, primarily due to the reduction of photoassimilate supply for reproductive drains. PRABHU et al. (2003) estimated productivity losses of $59.6 \%$ for non irrigated rice cultivation, attributed to the rice blast incidence in the leaves and panicles in natural conditions of a highland environment, in
Santo Antonio de Goiás.

The most important climatic factors for the disease development are the wetting of the leaves by the rains or by the dew. Temperatures between 20 and $27^{\circ} \mathrm{C}$ and air relative humidity superior than $90 \%$ favor sporulation and rapid development of the pathogen (FILLIPI et al., 2004; CASTEJÓN-MUÑOZ, 2008). The rain occurrence during this period reduces the rice blast severity in the panicles, carrying the spores and decreasing the initial inoculum quantity. The spore dissemination is lower in rainy days, being noticed a smaller incidence in highland rice in rainy years than in years with water deficiency (BEDENDO e PRABHU, 2005).

The higher susceptibility of leaves matches the season of nitrogen coverage fertilization. In these seasons, if conducted with high doses of fertilizers, over favorable climatic conditions and high plant density, may favor the development of the disease. LOBO et al. (2012) compared 5 doses of $\mathrm{N}(0,30$, $60,120,240 \mathrm{~kg} \mathrm{ha}^{-1}$ ) and 12 seasons of cultivation in weekly intervals. There was an increased severity of the disease in the panicles with fertilizer increase. The dose raise increased the chlorophyll content of the flag leaf, having a linear and positive relation with the disease severity. However, not only the dose, but also the parceling of nitrogen applications may influence the establishment of the disease. FAGERIA e PRABHU (2004) evaluated the parceling of nitrogen fertilization and verified that, in applying $90 \mathrm{~kg} \mathrm{ha}^{-1}$ of $\mathrm{N}$ and different doses of the pyroquilon fungicide, higher rice productivities were obtained when the application of nitrogen was divided in two (at the sowing and the active tillering, 45 days after the sowing) or three (sowing, active tillering and the early panicle) equal parts, and when there was fungicide application.

In fertilizations with high nitrogen doses in cultivated varieties susceptible to the rice blast, it is verified a greater necessity for fungicide use, due to the higher severity of the disease in panicle, which can raise the proportion of sterile spikelets, reducing the grain productivity in more than $20 \%$, and favoring a higher incidence of the pathogen in the reaped seeds (FREITAS et al., 2010).

Therefore, the use of chemical control through seed treatment with fungicide and foliar spraying has been indispensable for the obtaining of healthy plants in an integrated handling of the disease.

PRABHU e FILIPPI (2006) highlight that the genetic resistance of cultivated varieties is the 
main component of the integrated handling of rice blast. Recent works has studied more thoroughly the interaction plant-pathogen with the objective of finding sources of genetic resistance, and with use of molecular markers, new genes associated with the resistance has been discovered in the past few years (EIZENGA et al., 2006; XU et al., 2008; ZHU et al., 2012). Studies of the genome sequencing of the fungus causer of the disease have also been conducted (DEAN et al., 2005) and may bring new contributions for the programs of genetic improvement of the rice. It is verified that in many pathosystems the adoption of isolated techniques of disease control has showed inefficient, having, thus, the necessity of combination of control methods, known as integrated control. Depending on the cultivation system, the handling can be simple or complex.

In the Midwestern region of Brazil, in rice crops of highlands, only the anticipated sowing in the beginning of the rains controls effectively the blast in the leaves. In tropical environments, where the cultivation of irrigated rice is made intensively, as in Tocantins, the handling of the rice blast is complex, involving several factors, from sowing to harvest (PRABHU e FILIPPI, 2006). In this sense, the adoption of an efficient chemical control with fungicides, mainly in more susceptible cultivated varieties is important in order to guarantee the health and productivity of the culture. According to PRABHU e FILIPPI (2006), the use of fungicides is essential when the resistance of the cultivar is ineffective, and will continue as an important component due to its short durability of vertical resistance and to the gradual increase of cultivar susceptibility with partial resistance, both in highland rice and irrigated rice.

It is important to observe that, though the importance of the chemical control, some alternative strategy for avoiding the excessive dependence of fungicides such as silicon use through silicate correctives in the soil has been studied as a possible auxiliary strategy of the disease control. Some research results indicate that the silicon would create a mechanic barrier to the fungus penetration (SANTOS et al., 2009; DATNOFF et al., 1997). FILIPPI et al. (2007) verified in an experiment in a greenhouse, in spraying plants 18 days after the emergence with an isolated avirulent of Magnaporthe oryzae, induction of resistance to the virulent fungus, associated with a significant decrease of the disease severity.

\section{Chemical Control}

Presently, six manners of systemic action (Table 1), totaling 25 fungicides registered in the Ministry of Agriculture, Livestock and Food Supply (MAPA) for rice blast control in Brazil (Table 2). Four products are exclusively recommended for application in seed treatment (TS), twenty for foliar applications, and one for both application manners. According to the proposed classification by the Fungicide Resistance Action Committee - FRAC (2013), of these action mechanisms, 4 are verified in products for seed treatment and 4 in products for

Table 1. Action manner of the systemic fungicides registered in the Ministry of Agriculture, Livestock and Food Supply in March of 2013 for Rice blast control in Brazil, according to the Fungicide Resistance Action Committee - FRAC (2013).

\begin{tabular}{|c|c|}
\hline Frac Code & Action manner \\
\hline A1 & Inhibits the ribosomal RNA synthesis, acting over the polymerase I RNA enzyme \\
\hline B1 & Acts in the cellular division, inhibiting the formation of $\beta$-tubulin \\
\hline $\mathrm{C} 2$ & $\begin{array}{c}\text { Acts inhibiting the complex II of the respiration, connecting to the complex of succinate- } \\
\text { reductase }\end{array}$ \\
\hline $\mathrm{C} 3$ & $\begin{array}{l}\text { Acts in the inhibition of the complex III of the respiration, blocking the electron transfer in the } \\
\text { Complex cytochrome bc1 in the Qo site, interfering in the ATP production }\end{array}$ \\
\hline $\mathrm{E} 2 *$ & Interferes in the enzyme transduction of signs by MAP/ histidine-kinase \\
\hline G1 & $\begin{array}{l}\text { Interferes in the formation and selectivity of the plasma membrane, through the demethylation } \\
\text { of position } 14 \text { of lanosterol, inhibiting the sterol synthesis }\end{array}$ \\
\hline I1 & Melanin synthesis inhibitors \\
\hline $\mathrm{M}^{*}$ & $\begin{array}{c}\text { Contact mechanism with multi-site activity, characterized by the general interference of cellular } \\
\text { functions }\end{array}$ \\
\hline
\end{tabular}

* groups whose active wregistered ingredients are not systemic. 
Blast disease in rice culture

El Añublo del arroz

Brusone na cultura do arroz foliar applications, having two common for both treatment manners (Table 2). There are also more specific technical recommendations, not only for rice blast, but also for other diseases, for irrigated rice in the South of Brazil.

\section{Control via seed treatment}

The seed has been assuming more and more an important role in the control of crop diseases, constituting itself as a sort of "Carrier" of products that, by its application form, are promptly available to the plant when necessary (PICININI and GOULART, 2002).

The treatment of rice seeds with systemic fungicides, such as carboxin+thiram, pyroquilon and thiabendazole, may give an effective protection in the vegetative phase against the primary infection derived of inoculum from next or previous rice crops in the same area (BEDENDO e PRABHU, 2005).

FAGERIA e PRABHU (2004), evaluating the response of irrigated rice to nitrogen application

Table 2. Systemic fungicides registered in the Ministry of Agriculture, Livestock and Food Supply ${ }^{1}$, for rice blast control in Brazil in the year of 2013.

\begin{tabular}{|c|c|c|c|c|}
\hline $\begin{array}{l}\text { Action } \\
\text { manner }\end{array}$ & Chemical Group & Common Name & Commercial Name & $\begin{array}{l}\text { Application } \\
\text { Form }\end{array}$ \\
\hline $\mathrm{A} 1+\mathrm{E} 2$ & acylalanine+phenylpyrrole & metalaxyl-M+fludioxonil2 & Maxim XL & \\
\hline $\mathrm{B} 1+\mathrm{M}$ & benzimidazole+dithiocarbamate & carbendazim+thiram2 & Derosal Plus & \\
\hline $\mathrm{C} 2+\mathrm{M}$ & $\begin{array}{c}\text { oxathiin-carboxamide }+ \\
\text { dithiocarbamate }\end{array}$ & carboxin + thiram 2 & Vitavax-Thiram WP & $\begin{array}{c}\text { Seed } \\
\text { Treatment }\end{array}$ \\
\hline $\mathrm{C} 2+\mathrm{M}$ & $\begin{array}{l}\text { oxathiin-carboxamide }+ \\
\text { dithiocarbamate }\end{array}$ & carboxin + thiram 2 & Vitavax-Thiram 200 SC & \\
\hline $\mathrm{I} 1$ & Triazolobenzothiazole & Tricyclazole & $\operatorname{Bim} 750 \mathrm{R}$ & $\begin{array}{c}\text { Seed and } \\
\text { Foliar } \\
\text { Treatment }\end{array}$ \\
\hline $\mathrm{B} 1+\mathrm{M}$ & tiophanate+dithiocarbamate & $\begin{array}{c}\text { thiophanate- } \\
\text { methyl+mancozeb2 }\end{array}$ & Dithiobin $780 \mathrm{WP}$ & \multirow{18}{*}{ Foliar } \\
\hline $\mathrm{C} 3$ & methoxy-acrylate (estrobilurina) & Azoxystrobin & Priori & \\
\hline \multirow{13}{*}{ G1 } & \multirow{13}{*}{ Triazole } & \multirow{10}{*}{ Tebuconazole } & Rival 200 EC & \\
\hline & & & Elite & \\
\hline & & & Tebufort & \\
\hline & & & Array 200 EC & \\
\hline & & & Alterne & \\
\hline & & & Folicur EC & \\
\hline & & & Folicur 200 EC & \\
\hline & & & Egan & \\
\hline & & & Triade & \\
\hline & & & $\begin{array}{c}\text { Constant } \\
\text { Tebuconazole CCAB } \\
\text { 200 EC }\end{array}$ & \\
\hline & & Propiconazole & $\begin{array}{c}\text { Bumper } \\
\text { Juno }\end{array}$ & \\
\hline & & & Eminent $125 \mathrm{EW}$ & \\
\hline & & Tetraconazole & & \\
\hline \multirow{3}{*}{$\mathrm{G} 1+\mathrm{C} 3$} & \multirow{3}{*}{$\begin{array}{c}\text { triazole }+ \text { oximino-acetate } \\
\text { (estrobilurina) }\end{array}$} & tebuconazole + trifloxystrobin3 & Nativo & \\
\hline & & $\begin{array}{c}\text { propiconazole }+ \\
\text { trifloxystrobin3 }\end{array}$ & Stratego 250 EC & \\
\hline & & $\begin{array}{c}\text { epoxiconazole+kresoxim- } \\
\text { methyl2 }\end{array}$ & Brio & \\
\hline
\end{tabular}

1 Source: AGROFIT (2003) 2 Contact fungicide; 3 Mesostemic fungicide 
seasons and to seed treatments with the systemic fungicide pyroquilon, in seed treatment for rice blast control, verified that, with a dose of 200 grams of the fungicide per $100 \mathrm{~kg}$ of seeds, the rice production increased significantly in relation to the untreated seeds, and did not differ from the 400 grams dose of fungicide per $100 \mathrm{~kg}$ of seeds.

REIS et al. (2007) considered both the pyroquilon and tricyclazole fungicides, specific for rice blast control. The affirmation of the authors can be confirmed by ZEMOLIN et al. (2007), who found rice blast control superior than $90 \%$ by the active ingredients of pyroquilon in the dose correspondent to $4.0 \mathrm{~g}$ and tricyclazole in doses of 1.875 and $2.25 \mathrm{~g}$ i.a. $\mathrm{kg}^{-1}$ of seeds. But also obtained good results with the mix of carboxin+thiram, which presented an $88.55 \%$ efficiency in the rice blast control.

LOBO (2008) also obtained good results for rice blast control in leaves with pyroquilon and azoxystrobin, in rice seed treatment. LOBO (2004a) comments that the tricyclazole and azoxystrobin fungicides are recommended for the rice blast control via foliar application; however, producers have been using these products to treat their seeds. According to the author, these fungicides, when applied in the seed treatment, presented a good disease control in the leaves and it was not verified phytotoxicity or other problems with its utilization

The fact that the tricyclazole and azoxystrobin, even without recommendation, were used for seed treatment, comes from the operational practicality, in view of the possibility of two products of different action mechanisms be used on two application manners. Nevertheless, this can also be dangerous, since the efficiency of these products may be compromised, through the excessive use, causing selection pressure on the pathogen's pathosystem.

This way, the rational usage of these fungicide molecules is important to an efficient long-term handling system of diseases, in order to avoid problems such as the selection of resistant individuals.

KUNOVA et al. (2013), in a study in vitro, found that the mycelium growth of Magnaporthe oryzae was inhibited to low concentrations of azoxystrobin and to relatively high concentrations of tricyclazole, while the sporulation was sensitive to both fungicides and was affected by low doses in a similar way. Furthermore, the infection of conidia obtained from mycelia exposed to tricyclazole was affected in greater extent than conidia produced in an environment altered by azoxystrobin, though the germination of such conidia had also been decreased after treatment with azoxystrobin. According to the authors, the high effectiveness of the tricyclazole against the sporulation inhibition and secondary infection indicate a possible manner of additional action of this fungicide different from the melanin biosynthesis inhibition.

ZHANG et al. (2009), after a study about the development of rice blast resistance to tricyclazole, suggest that this fungicide has low risk of developing resistant pathogens and that the resistance will not occur in the period of 6 to 10 years in China. However, it does not guarantee that the resistance won't develop. Thus, they suggest that the product must be used mixed with other fungicides, or in alternative rotations with different action manners, in order to minimize any risk of developing resistance.

Recently, the tricyclazole was pointed as a much used fungicide for rice blast control in Brazil and in other producer countries, such as China (PRABHU e FILIPPI, 2006; ZHANG et al., 2006). The systemic activity of tricyclazole in rice has been demonstrated in the control of rice blast symptoms in the leaves, indirectly by the seed treatment, and directly based on the presence of compound in the foliar tissues, being 25 to 35 times more efficient in vivo than in vitro in the inhibition of the rice blast agent (PRABHU e FILIPPI, 2006).

For this same authors commented that the rice blast control by seed treatment with pyroquilon, in the State of Tocantins, had its effectiveness decreased in relation to previous years, verified with the considerable reduction of the product residual effect, and anticipation of the beginning of lesions in the leaves up to 20 to 30 days after the sowing, instead of 40 to 45 , as previously. Some hypotheses for these problems would be the continuous use of the product, adoption of sub doses, and also the elevated pressure of the disease, due to the use of cultivated varieties with high susceptibility to the rice blast.

AZEVEDO (2007) argues that the pyroquilon is a product with excellent metabolic stability, presents good systemic effect and has a residual period up to 55 days in rice cultivation. But, according to the author, since 2002 this fungicide is out of the market, with any other commercial product listed in the Agrofit system. The reasons to the end of the product's commercialization are not public, but through the literature it is possible to observe that it was an important tool for the rice blast handling via seed treatment. In field experiments, TEIXEIRA et 
Blast disease in rice culture

El Añublo del arroz

Brusone na cultura do arroz al. (1997) found more efficiency and residual effect of the pyroquilon fungicide in relation to other active ingredients, such as the carboxin+thiram, difenoconazole, fludioxonil and thiabendazole, in the control of rice blast in the leaves. It is also found that there are no commercial products registered presently with the thiabendazole ingredient, formerly pointed to the disease control.

In experiments of fungicide evaluation applied in rice seed treatment, in four susceptible cultivated varieties, in the State of Goiás, LOBO (2004a) verified, under favorable conditions to the fungus and high pressure of the inoculum, that the treatments with carboxin+thiram and tiophanatemethyl, in its respective doses, did not reduce the rice blast control in the leaves. But the author argues that, in previous essays, and even in commercial crops, the mixture carboxin+thiram proved efficient, and even improved the germination and vigor of contaminated seeds.

ZEMOLIN et al. (2007) found that the mixture carboxin+thiram was the product which less reduced the number of seeds infected with Magnaporthe grisea, in relation to the tricyclazole and pyroquilon, but obtained $88.55 \%$ control efficiency, which can also be interesting, as long as inserted correctly in a program of disease management, becoming an option on the control and prevention of emergence of resistance to the used fungicides, knowing that the pyroquilon is no longer commercialized. The action manner of the pyroquilon, in the plant, as well as the tricyclazole, is the inhibition of melanin biosynthesis of the cellular wall (FRAC, 2013).

The active ingredient metalaxyl-M+fludioxonil was recently registered for rice blast in the MAPA, which can justify the scarcity of scientific works of evaluating of this fungicide over the disease. ARSEGO et al. (2006), in comparing this fungicide with the carboxin+thiram, associated to different doses of gibberellic acid (GA), obtained, for two products, germination percentages next to $95 \%$, when there was no GA. The authors report, though, that with a GA addition, the emergence percentage was inferior to that of the seeds coated with carboxim +thiram. Studies with the use of this fungicide are found more often in other cultures. As an example, PINTO (2004) verified that this fungicide was associated with greater sorghum seedling emergence in function of the control of pathogenic fungi associated with seeds present in the soil, having effective control over the Penicillium spp., Alternaria tenuis, Phoma sorghina, Curvularia lunata and Drechslera túrcica. In soy, LUDWIG et al. (2011) associated the treatment with this fungicide to the decrease of incidence of Rhizoctonia sp., Colletotrichum sp., Phomopsis sp. e Alternaria sp.

\section{Control via foliar spray}

In crops that had its seeds treated with systemic fungicides for rice blast control, it is not advisable the spraying with foliar fungicides for rice blast control in the leaves until a period of 30 to 40 days after the sowing. In irrigated rice, the irrigation water availability in the period of 20 to 25 days after the sowing is advisable, because the level of control with irrigation is the same obtained with fungicide, in this phase (PRABHU e FILIPPI, 2006). However, CORNÉLIO et al. (2000) point out that the Pyricularia grisea attacks in similar way the material sowed in traditional rainfed conditions and under irrigation by aspersion.

According to PRABHU et al. (2002), the chemical control against the rice blast in the panicles is more important in cultivated varieties susceptible or moderately susceptible. The chemical control with foliar spray must be considered an essential tool inside a plan of integrated handling of rice blast, since it is necessary to the protection of panicles against the infection of Pyricularia grisea. The economic viability and the number of application depend on the resistance degree of the cultivar, the climatic conditions, the application cost, the adopted cultivation practices and the rice price.

There is not yet a secure method of occurrence prediction of rice blast in the panicles, based on the blast incidence in the leaves. The blast in the panicles starts seven to ten days after the emission of panicles and progresses successively until ripeness (PRABHU e FILIPPI, 2006). The spraying with fungicide for rice blast control can be done once, in panicle emission season, or twice, with 10 days interval after the first (FAGERIA et al., 1995). The delay on the beginning of the rice blast epidemic in the panicles, postponing the disease incidence to a posterior phase of the critical period (milky stage of grains), minimizes the damages on productivity and grain quality.

DARIO et al. (2005), evaluating different fungicides for foliar control in rice blast, with two sequential applications (80 and 90 days after emergence), in the stages of booting and complete flourishing, respectively, concluded, in an irrigated 
production system whose control plants reached an average value of infected foliar area of $82.5 \%$, that the application of the fungicides trifloxystrobin, propiconazole, fluoxystrobin and tebuconazole, under the proposed doses, were efficient on the rice blast control.

PRABHU et al. (2002), in reviewing data of 4 experiments of response evaluation of the rice cultivar Caiapó to the application of fungicides on the blast control in the panicles and productivity, observed that the tricyclazole fungicide provided greater reduction of the rice blast severity in the panicles in relation to the tebuconazole and higher productivity in relation to control treatment when applied in the panicle emission phase. One or two applications of tricyclazole did not differ regarding the disease control. But, in case of the need of two applications, recommended the first foliar application of fungicide at ten days before the panicle emission and the second in the panicle emission season ( 1 to $5 \%$ of emitted panicles).

LOBO (2004b), evaluating the fungicide use for rice blast control, verified that less severity in the panicle was observed in treatments with trifloxystrobin+tebuconazole, and with tricyclazole, whereas these treatments did not differ between themselves, nor from the treatments with azoxystrobin and trifloxystrobin+cyproconazole, these last two not differing from control treatment. In relation to productivity, only the treatment with higher dose of trifloxystrobin+tebuconazole $\left(100+200 \mathrm{~mL} \mathrm{ha}^{-1}\right)$ outperformed the control treatment, not differing, though, from the other fungicides.

GONÇALVES et al. (2012), in evaluating different fungicides in rice cultures, in two applications, at 75 and 85 days after emergence, verified that the active ingredients azoxystrobin and trifloxystrobin+propicanozole reduced the rice blast severity in the panicles in approximately $50 \%$, in comparison with the treatment without any fungicide application.

\section{Conclusions}

The rice blast is considered the most important disease in rice cultivation. The chemical control, through seed treatment and foliar spray with fungicides, associated with other integrated handling measures, complements expressively the control of this disease.

The treatment with systemic fungicides has shown itself efficient in chemical control, for promoting, in many times, healing, protecting and eradicative effects of the disease.

In the planning of the rice blast chemical control, it is important to take into account the occurrence of other diseases that may cause damages to the culture, either productivity lost or grain quality, in order to choose the best control method and the possible fungicide products that may prevent economic harm in the cultivation.

\section{References}

AGROFIT: Sistema de Agrotóxicos Fitossanitários. Ministério da Agricultura, Pecuária e Abastecimento, Coordenação-Geral de Agrotóxicos e Afins. 2003. Disponível em: http:/ / agrofit.agricultura.gov.br/agrofit_ cons/principal_agrofit_cons>. Acesso em: 22 mar. 2013.

ARSEGO, O.; BALDET, L.; AMARAL, A.S.; HÖLBIG, L.; PESKE, F. Recobrimento de sementes de arroz irrigado com ácido giberélico, fungicidas e polímero. Revista Brasileira de Sementes, v.28, n.2, p.201-206, 2006.

AZEVEDO, L.A.S. Fungicidas Sistêmicos: teoria e prática. 1.ed. Campinas: EMOPI, 2007, 284p.

BASTIAANS, L. Effects of leaf blast on photosynthesis of rice. 1. Leaf photosynthesis. Netherlands Journal of Plant Pathology, v.99, p.197-203, 1993.

BASTIAANS, L.; KROPFF, M.J. Effects of leaf blast on photosynthesis of rice. 2. Canopy photosynthesis. Netherlands Journal of Plant Pathology, v.99, p.205-217, 1993.

BASTIAANS, L.; ROUMEN, E.C. Effect on leaf photosynthetic rate by leaf blast for rice cultivars with different types and levels of resistance. Euphytica, v.66, p.81-87, 1993.

BEDENDO, I.P.; PRABHU, A.S. Doenças do Arroz (Oryza sativa). In: KIMATI, H.; AMORIM, L.; REZENDE, J.A.M.; BERGAMIN FILHO, A.; CAMARGO, L.E.A. (Ed.). Manual de Fitopatologia: Doenças das Plantas Cultivadas. 4.ed. São Paulo: Ceres, 2005, p.79-90.

Applied Research \& Agrotecnology v7 n2 may/sep. (2014)

Print-ISSN 1983-6325 (On line) e-ISSN 1984-7548 
Blast disease in rice culture

El Añublo del arroz

Brusone na cultura do arroz p. $109-119$

CASTEJÓN-MUNOZZ, M. The effect of temperature and relative humidity on the airbone concentration of Pyricularia oryzae spores and the development of rice blast in southern Spain. Spanish Journal of Agricultural Research, v.6, n.1, p.61-69, 2008.

CORNÉLIO, V.M.O.; SANTOS, P.G.; SOARES, A.A.; LOPES, T.L.V. Associação entre a incidência de brusone e a presença de Pyricularia grisea nas sementes de arroz. Pesquisa Agropecuária Brasileira, Brasília, v.35, n.3, p.639-645, 2000.

CRUZ, R.P.; MILACH, S.C.K. Melhoramento genético para tolerância ao frio em arroz irrigado. Ciência Rural, v.30, n.5, p.909-917, 2000.

DARIO, G.J.A.; MANFRON, P.A.; BONNECARRÉR, A.G.; DOURADO NETO, D.; MARTIN, T.N.; CRESPO, P.E.N. Controle químico de brusone em arroz irrigado. Revista da FZVA, v.12, n.1, p.25-33. 2005.

DATNOFF, L.E.; DEREN, C.W. SNYDER, G.H. Silicon fertilization for disease management of rice in Florida. Crop Protection, v.16, n.6, p.525-531, 1997.

DEAN, R.A.; TALBOT, N.J.; EBBOLE, D.J.; FARMAN, M.L.; MITCHELL, T.K.; ORBACH, M.J.; THON, M.; KULKARNI, R.; XU, J.-R.; PAN, H.; READ, N.D.; LEE, Y.-H.; CARBONE, I.; BROWN, D.; OH, Y.Y.; DONOFRIO, N.; JEONG, J.S.; SOANES, D.M.; DJONOVIC, S.; KOLOMIETS, E.; REHMEYER, C.; LI, W.; HARDING, M.; KIM, S.; LEBRUN, M.-H.; BOHNERT, H.; COUGHLAN, S.; BUTLER, J.; CALVO, S.; MA, L.-J.; NICOL, R.; PURCELL, S.; NUSBAUM, C.; GALAGAN, J. E. \& BIRREN, B. W. The genome sequence of the rice blast fungus Magnaporthe grisea. Nature, v.434, n.7036, p.980-986, 2005.

EIZENGA, G.C.; AGRAMA, H.A.; LEE, F.N.; YAN, W.; JIA, Y. Identifying novel resistance genes in newly introduced blast resistant rice germplasm. Crop science, v.46, p.1870-1878, 2006.

ERWIN, D.C. Systemic fungicides: disease control, translocation, and mode of action. Annual Review of Phytopathology, v.11, p.389-422, 1973.

FAGERIA, N.K.; FERREIRA, E.; PRABHU, A.S.; BARBOSA FILHO, M.P.; FILIPPI, M. C. Seja o doutor de seu arroz. Piracicaba: Potafos, 1995. 20p. (Arquivo do Agrônomo, 9).

FAGERIA, N.K.; PRABHU, A.S. Controle de brusone e manejo de nitrogênio em cultivo de arroz irrigado. Pesquisa Agropecuária Brasileira, v.39, n.2, p.123-129, 2004.

FAO. FAO Statistical Yearbook 2012: World food and agriculture. Rome, 2012. 362p.

FILIPPI, M.C.; PRABHU, A.S.; SILVA, G.B. Doenças e métodos de controle. In: SANTOS, A. B.; BIAVA, M. (Ed.). Cultivo do arroz irrigado no estado do Tocantins. Santo Antônio de Goiás: Embrapa Arroz e Feijão, 2004. (Sistemas de Produção, n.3). Disponível em: http:/ / sistemasdeproducao.cnptia.embrapa.br/FontesHTML/ Arroz/ArrozIrrigadoTocantins/doencas_metodo_controle.htm. Acesso em: 20 fev. 2013.

FILIPPI, M.C.C; SILVA, G.B.; PRABHU, A.S. Indução de Resistência à Brusone em Folhas de Arroz por Isolado Avirulento de Magnaporthe oryzae. Fitopatologia Brasileira, v.32, p.387-392, 2007.

FREITAS, J.G.; MALAVOLTA, V.M.A.; SALOMON, M.V.; CANTARELLA, H.; CASTRO, L.H.S.H.; AZZINI, L.E. Adubação nitrogenada e incidência de brusone em arroz de sequeiro. Bragantia, v.69, n.1, p.173-179, 2010.

FUNGICIDE RESISTANCE ACTION COMMITEE. FRAC Code List 2013: Fungicides sorted by mode of action (including FRAC code numbering). Disponível em: http:/ / www.frac.info/publication/anhang/FRAC\%20 Code\%20List\%202013-final.pdf. Acesso em: 13 mar. 2013.

GARCÍA, P.C.; RIVERO, R.M.; RUIZ, J.M.; ROMERO, L. The role of fungicides in the physiology of higher plants: implications for defense responses. The Botanical Review, v.62, n.2, p.162-172, 2003.

GONÇALVES, F.J.; ARAUJO, L.G.; SILVA, G.B.; FILIPPI, M.C.C. Controle químico da brusone em arroz de terras altas: efeitos nos fungos não alvos do filoplano. Pesquisa Agropecuária Tropical, v.42, n.1, p.77-81, 2012.

GUIMARÃES, E.P.; SANTOS, A.B.; MAGALHÃES JÚNIOR, A.M; STONE, L.F. Sistemas de cultivo. In: SANTOS, A. B.; STONE, L. F.; VIEIRA, N. R. A. (Ed.). A cultura do arroz no Brasil. 2.ed. Goiânia: Embrapa Arroz e Feijão, 2006. p.53-96.

Applied Research \& Agrotecnology v7 n2 may/sep. (2014)

Print-ISSN 1983-6325 (On line) e-ISSN 1984-7548 
KNIGHT, S.C.; ANTHONY, V.M.; BRADY, A.M.; GREENLAND, A.J.; HEANEY, S.P.; MURRAY, D.C.; POWELL, K.A.;SCHULZ, M.A.; SPINKS, C.A.; WORTHINGTON, P.A.; YOULE, D. Rationale and perspectives on the development of fungicides. Annual Review of Phytopathology, v.35, p.349-372, 1997.

KUNOVA, A.; PIZZATTI.; CORTESI, P. Impact of tricyclazole and azoxystrobin on growth, sporulation and secondary infection of the rice blast fungus, Magnaporthe oryzae. Pest Management Science, v.69, p.278-284, 2013.

LOBO, V.L.S. Effects of chemical treatment of rice seeds on leaf blast control and physiological and sanitary quality of treated seeds. Tropical Plant Pathology, v.33, p. 162-166. 2008.

LOBO, V.L.S. Tratamento de Sementes para o Controle da Brusone nas Folhas em Arroz. Santo Antônio de Goiás: Embrapa Arroz e Feijão. 2004a. 4p. (Comunicado Técnico 77).

LOBO, V.L.S. Tratamento Químico para o Controle da Brusone na Panícula. Santo Antônio de Goiás: Embrapa Arroz e Feijão. 2004b . 4p. (Comunicado Técnico 78).

LOBO, V.L.S.; FILIPPI, M.C.; SILVA, G.B.; VENANCIO, W.L.; PRABHU, A.S. Relação entre o teor de clorofila nas folhas e a severidade de brusone nas panículas em arroz de terras altas. Tropical Plant Pathology, v.37, p.83-87, 2012.

LUDWIG, M.P.; LUCCA FILHO, O.A.; BAUDET, L.; DUTRA, L.M.C.; AVELAR, S.A.G.; CRIZEL, R.L. Qualidade de sementes de soja armazenadas após recobrimento com aminoácido, polímero, fungicida e inseticida. Revista Brasileira de Sementes, v.33, n.3 p.395-406, 2011.

MELLO, A.P.A.; URASHIMA, A.S. Diversidade da virulência de Pyricularia grisea num local de melhoramento genético de arroz. Fitopatologia Brasileira, v.28, n.5, p. 541-543, 2003.

PICININI, E.C.; GOULART, A.C.P. Novos fungicidas para tratamento de sementes. In: LUZ, W.C.; FERNANDES, J.M.C.; PRESTES, A.M.; PICININI, E.C. (Ed.). Revisão Anual de Patologia de Plantas. Passo Fundo, v.10, p.33-66, 2002.

PINTO, N.F.J.A. Avaliação da eficiência dos fungicidas fludioxonil + metalaxyl-M no tratamento de sementes de sorgo. Ciência e Agrotecnologia, v.28, n.2, p.450-453, 2004.

PRABHU, A.S.; ARAÚJO, L.G.; FAUSTINA, C.; BERN, R.F.B. Estimativa de danos causados pela brusone na produtividade de arroz de terras altas. Pesquisa Agropecuária Brasileira, v.38, n.9, p.1045-1051, 2003.

PRABHU, A.S.; FILIPPI, M.C. Resistência da cultivar no manejo integrado da brusone. In: PRABHU, A. S.; FILIPI, M. C. Brusone em arroz: controle genético, progresso e perspectivas. Santo Antônio de Goiás: EMPBRAPA Arroz e Feijão, 2006, p. 323-379.

PRABHU, A.S.; FILIPPI, M.C.C.; RIBEIRO, A.S. Doenças e seu Controle. In: SANTOS, A. B.; STONE, L. F.; VIEIRA, N. R. A. (Ed.). A cultura do arroz no Brasil. 2.ed, Santo Antônio de Goiás: Embrapa Arroz e Feijão, 2006. p.561-631.

PRABHU, A.S.; GUIMARÃES, C.M.; SILVA, G.B. Manejo da Brusone no Arroz de Terras Altas. Santo Antônio de Goiás: Embrapa Arroz e Feijão. 2002. 6p. (Circular Técnica 52).

REIS, E.M.; REIS, A.C.; FORCELINI, C.A. Manual de Fungicidas: guia para o controle químico de doenças em plantas. 5.ed. Passo Fundo: UPF, 2007. 153p.

SANTOS, A.B.; PRABHU, A.S.; FERREIRA, E.; FAGERIA, N.K. Fertilização silicatada na severidade de brusone e na incidência de insetos-praga em arroz irrigado. Revista Brasileira de Engenharia Agrícola e Ambiental, v.13, n.5, p.537-543, 2009.

TEIXEIRA, E.A.; FILIPPI, M.C.; PRABHU, A.S. Eficiência relativa dos fungicidas sistêmicos, no tratamento de sementes para o controle da brusone nas folhas de arroz. Revista Brasileira de Sementes, v.19, n.2, p.179184, 1997.

TENG, P.S. The epidemiological basis for blast management. In: ZEIGLER, R. S.; LEONG, S. A.; TENG, P. S. (Ed.). Rice Blast Disease. Wallingford: CAB International, 1994. p.409-433.

Applied Research \& Agrotecnology v7 n2 may/sep. (2014)

Print-ISSN 1983-6325 (On line) e-ISSN 1984-7548 
XU, X.; CHEN, H.; FUJIMURA, T.; KAWASAKI. Fine mapping of a strong QTL of Weld resistance against rice blast, Pikahei-1(t), from upland rice Kahei, utilizing a novel resistance evaluation system in the greenhouse. Theoretical and Applied Genetics, v.117, p.997-1008, 2008.

ZEMOLIN, C.R., GULART, C.; LENZ, G.; BAYER, T. COSTA, I.F.D. Eficiência de fungicidas aplicados em sementes de arroz visando o controle da brusone (Magnaporthe grisea). Revista da FZVA, v.14, n.1, p.81-88, 2007.

ZHANG, C.G.; HUANG, H.; WANG, J.X.; ZHOU, M.G. Resistance development in rice blast disease caused by Magnaporthe grisea to tricyclazole. Pesticide Biochemistry and Physiology, v.94, p.43-47, 2009.

ZHANG, C.Q.; ZHU, G.N.; MA, Z.H.; ZHOU, M.G. Isolation, characterization and preliminary genetic analysis of laboratory tricyclazole-resistant mutants of the rice blast fungus, Magnaporthe grisea. Journal Phytopathology, Berlim, v.154, p.392-397, 2006.

ZHU, X.; CHEN, S.; YANG, J.; ZHOU, S.; ZENG, L.; HAN, J.; SU, J.; WANG, L.; PAN, Q. The identification of Pi50(t), a new member of the rice blast resistance Pi2/Pi9 multigene family. Theoretical and Applied Genetics, v.124, p.1295-1304, 2012. 